\title{
Thematic Issue on the Hydrological Effects of the Vegetation-Soil Complex
}

\author{
Paul D. Hallett ${ }^{1}$, Giora J. Kidron ${ }^{2}$, Radka Kodešová ${ }^{3}$, L’ubomír Lichner ${ }^{4}$ \\ ${ }^{1}$ Institute of Biological \& Environmental Sciences, University of Aberdeen, Aberdeen AB24 3UU, United Kingdom. \\ ${ }^{2}$ Hebrew University of Jerusalem, Institute of Earth Sciences, Givat Ram Campus, IL-91904 Jerusalem, Israel. \\ ${ }^{3}$ Department of Soil Science and Soil Protection, Faculty of Agrobiology Food and Natural Resources, Czech University of Life Sciences \\ Prague, Kamýcká 129, 16521 Prague 6, Czech Republic. \\ ${ }^{4}$ Institute of Hydrology, Slovak Academy of Sciences, Dúbravská 9, 84104 Bratislava, Slovakia.
}

The Journal of Hydrology and Hydromechanics (JHH) has published numerous thematic issues over the past few years covering topics such as hydrological extremes (4/2016), hydrological interactions between soil and vegetation (2/2016), catchment hydrology $(3 / 2015)$, and two issues on biological and hydrological interactions in soil, termed Biohydrology $(4 / 2014 ; 1 / 2013)$. This issue follows the success of previous Thematic Issues focussing on the Hydrological Effects of the Vegetation-Soil Complex. It marks the $4^{\text {th }}$ Biohydrology Conference, being held from 13-16 September, 2016 in Almeria, Spain (see http://www.biohydrology2016.es/), with a collection of 10 novel studies from researchers located across the globe.

Biohydrology has grown as a discipline as the interdependency between biology and hydrology in soil has become increasingly appreciated. This has stemmed from major societal concerns about climate change, food security and water challenges, which Sir John Beddington, the UK's chief scientist in 2009 coined the 'perfect storm' between famine and prosperity. We are challenged with producing more food with less water, with processes as subtle as night-time wetting of plant leaves affecting transpirational losses during the day (Yasutake et al., 2015). Soil may also constrain the capacity of plant roots to access deeper water if compacted layers impede growth to shallow surface soils that dry more rapidly (Josa et al., 2015). Greater water use efficiency needs to be achieved against a landscape of continually degrading soil conditions, where processes such as water repellency (Ward et al., 2015), organic matter decline (Rajkai et al., 2015) and unstable soil structure (Leelamanie et al., 2015) have a negative impact on soil water infiltration and storage. Negative changes to interactive processes between hydrology and biology exacerbate soil degradation, such as runoff and sediment loss associated with water erosion.

Vegetation and organic matter have been appreciated to be major controlling factors of soil erosion for decades, but only recently has a surge of systematic studies explored underlying biological processes such as direct stabilisation by plant roots (De Baets et al., 2008), preferential transport of water along root channels (Kodešová et al., 2015), soil structure regeneration by biology (Hallett et al., 2013; Surda et al., 2015) and the spatial alteration to wetting properties (Sándor et al., 2015), often driven by soil water repellency (Pekárová et al., 2015; Ward et al., 2015). In sub-Saharan Africa the impacts are particularly severe, but conservation practices combining vegetation, soil management and physical barriers along slopes to impede water flow have proven to be highly successful at capturing water and decreasing erosion impacts (Dagnew et al., 2015). From new understanding combining biology and hydrology, novel solutions to the global challenges of food and water security are being found. There is also great opportunity to understand successive stages of reclamation of highly de- graded land by biology. Gypser et al. (2016) in the last issue of JHH found a very large impact of biological soil crusts on water infiltration and retention in a reclaimed mine soil.

Another surge of research in Biohydrology has come from a desire to understand how the earth works. Natural terrestrial systems are strongly controlled by hydrology (Zhao et al., 2011), so much so that some vegetation may make soils wetter or drier, creating conditions for their own ecological benefit (Cammeraat and Kooijman, 2009). As hydrological conditions change with droughts and extreme precipitation events associated with climate change, the interactions between biology and hydrology in natural terrestrial systems may be severely affected. There is evidence that water uptake by vegetation during summer droughts decreases the capacity of soils to subsequently retain water in wet winters (Robinson et al., 2016). In dry summers, water repellency can affect water flow and storage in semi-natural soils such as grasslands, causing losses from preferential flow through the soil matrix to groundwater (Rodný et al., 2015).

Biology clearly interacts with hydrology with mixed effects depending on vegetation, microorganisms, fauna, soil and climate. This Thematic Issue on the Hydrological Effects of the Vegetation-Soil Complex advances understanding even further with 10 new papers studying a range of land uses, ecosystems and environmental challenges. Water availability for crop production is one such challenge, which Lehoczky et al. (this issue) found for maize to be strongly affected by fertiliser inputs and the control of weeds. Their full factorial experiment examined contributions of $\mathrm{N}, \mathrm{P}$ and $\mathrm{K}$ in different combinations, with fertilised plots not controlled for weeds having a different distribution of water down the soil profile to $80 \mathrm{~cm}$ depth than plots with weeds. When the crop grew well under a fertilised regime, water content depleted rapidly at early growth stages, with impacts to crop biomass production. These impacts need more consideration in crop growth simulation models, with the research presented by Klement et al. (this issue) improving such understanding. They grew barley and wheat in root growth chambers under controlled glasshouse conditions, and applied a combination of gravimetric (root excavation and weighing) and imaging approaches to quantify the spatial distribution of plant roots. HYDRUS modelling explored the impacts of root distribution on water uptake. A significant finding of this study was that the depth of root growth had a much greater impact on soil water distribution than the horizontal proliferation of roots.

Research is also presented on semi-natural systems. In the semi-arid climate of the Loess Plateau in China, Jian et al. (this issue) demonstrated the close interaction between soil moisture distribution, sap flow and plant species. After rainfall events, they found species specific impacts on the increase in sap flow rates, which they argued could shape plant composition in this environment under predicted changes of rainfall. Rainfall 
needed to penetrate deep into the soil profile before large increases in sap flow could be observed. Bachmann et al. (this issue) noted a lack of studies on processes controlling water infiltration and retention in deeper soils, particularly due to the occurrence of water repellency. They present results from a bold study in a temperate beech forest where trenches 3 metres long and 2 metres depth were sampled spatially along their faces to measure the variability of contact angles and the influence of $\mathrm{pH}$, depth and organic matter. Although it is widely thought that water repellency is a feature of shallow surface soils, Bachmann et al. (this issue) observed contact angles of $60-75^{\circ}$ for soils with $\mathrm{pH}<3.5$ at deeper depths, with values less than $10^{\circ}$ if $\mathrm{pH}>4.0$. Ongoing acidification in the region combined with greater drought could exacerbate water repellency in the future. Such processes are not currently considered when predicting the impacts of climate change.

Drought dries soils and this is known to be closely related to the development of soil water repellency. Orfánus et al. (this issue) demonstrated the correlation between soil water content and water repellency for a grassland site located in the continental climate of central Europe. They found that some methods to calculate soil hydraulic conductivity, which is supposed to occur at steady-state, may be providing an underestimate because the impact of water repellency on early-time sorptivity has a large influence.

Biological effects on water repellency can be much greater in arid environments, particularly in the presence of biological crusts, where organisms exude potentially hydrophobic polysaccharide compounds. For biological soil crusts in the Negev Desert, Israel, Keck et al. (this issue) detected only small levels of soil water repellency and impacts over small spatial scales. They argued that the ecosystem impacts from water repellency alone would therefore be small, and that other mechanisms such as pore clogging and pore structure changes by biology could be having a greater influence on water infiltration and retention, as indeed shown (Kidron, 2014). Kidron (this issue) also studied biological soil crusts in the Negev Desert, focussing on soils derived from fluvial sediments. Crust development in his study was found to be controlled by spatial differences in soil properties, such as texture and its impact on water retention. The study proposes the use of biological soil crusts as biomarkers for surface moisture with a value of $>10 \mathrm{mg} \mathrm{m}^{-2}$ of chlorophyll $a$ content marking the threshold for the presence of biological soil crust.

Spatial variability in soil properties can also influence the development of soil water repellency at the aggregate scale. The surfaces of soil aggregates may be preferentially coated with a combination of organic matter and smaller-sized minerals, which Fér et al. (this issue) found to greatly exacerbate water repellency. They found for a clay-illuvial Bt-horizon of a Luvisol that aggregate surfaces had more hydrophobic organic compounds (determined by DRIFT spectroscopy) and greater water repellency. This was verified by comparing aggregates with coatings with natural aggregates where the coatings were absent and on coated aggregates that had their surfaces stripped.

A depletion of such organic matter coatings through intensive agriculture could therefore influence the rate of water infiltration into soil aggregates and their stability. Tropical soils, with their fast carbon mineralisation rates, are particularly prone to organic matter losses. Liyanage and Leelamanie (this issue) studied how organic matter additions influence water repellency and retention of an Acrisol from Sri Lanka. In their laboratory experiment they found a positive relationship between increased organic matter driven by manure inputs and soil water contact angle. Water retention was also improved by amendment with potentially hydrophobic organic compounds, with an interesting positive correlation between water repellency and water content near field capacity.

Organic matter does not always have a positive impact, and its introduction through wastewater streams can markedly enhance soil water repellency. Tamimi et al. (this issue) examined the seasonal influence of applying olive mill wastewater to soils, finding large amounts of phenolics, decreased $\mathrm{pH}$ and high levels of water repellency found in summer months. By applying olive mill wastewater in the spring, combined with careful irrigation, water repellency could be mitigated significantly, offering a solution to deal with this large waste stream.

The combined understanding of hydrology and biology presented in this series of papers has helped to explain water based drivers in the development of natural ecosystems and provided solutions to help tackle water and soil sustainability. Many more studies on this topic will be presented at the $4^{\text {th }}$ Biohydrology Conference, with a further special issue of the Journal of Hydrology and Hydromechanics planned for 2017 to highlight a few key studies from the meeting. Interdisciplinary research is essential to tackle many of the great challenges facing humanity, particularly related to food security, environmental degradation and climate. This Thematic Issues focussing on the Hydrological Effects of the Vegetation-Soil Complex presents research that helps tackle these challenges, and highlights the need for much more research on these topics in the future.

\section{REFERENCES}

Cammeraat, E.L.H., Kooijman, A.M., 2009. Biological control of pedological and hydro-geomorphological processes in a deciduous forest ecosystem. Biologia, 64, 428-432.

Dagnew, D.C., Guzman, C.D., Zegeye, A.D., Tibebu, T.Y., Getaneh, M., Abate, S., Zemale, F.A., Ayana, E.K., Tilahun, S.A., Steenhuis, T.S., 2015. Impact of conservation practices on runoff and soil loss in the sub-humid Ethiopian Highlands: The Debre Mawi watershed. J. Hydrol. Hydromech., 63, 210-219.

De Baets, S., Torri, D., Poesen, J., Salvador, M.P., Meersmans, J., 2008. Modelling increased soil cohesion due to roots with EUROSEM. Earth Surface Processes and Landforms, 33, 1948-1963.

Gypser, S., Veste, M., Fischer, T., Lange, P., 2016. Infiltration and water retention of biological soil crusts on reclaimed soils of former open-cast lignite mining sites in Brandenburg, north-east Germany. J. Hydrol. Hydromech., 64, 1-11.

Hallett, P.D., Karim, K.H., Bengough, A.G., Otten, W., 2013. Biophysics of the vadose zone: from reality to model systems and back again. Vadose Zone Journal, 12, doi: 10.2136/vzj2013.05.0090.

Josa, R., Ginovart, M., Mas, M.T., Verdú, A.M.C., 2015. Hardpan in skeletal soils: Statistical approach to determine its depth in a cherry orchard plot. Biologia, 70, 1433-1438.

Kidron, G.J., 2014. Sink plot (SP) for runoff measurements on semi-flat terrains: Preliminary data and their potential hydrological and ecological implications. J. Hydrol. Hydromech., 62, 303-308.

Kodešová, R., Němeček, K., Žigová, A., Nikodem, A., Fér, M., 2015. Using dye tracer for visualizing roots impact on soil structure and soil porous system. Biologia, 70, 1439-1443.

Leelamanie, D.A.L., Mapa, R.B., 2015. Alterations in soil aggregate stability of a tropical Ultisol as mediated by changes in land use. Biologia, 70, 1444-1449. 
Pekárová, P., Pekár, J., Lichner, L., 2015. A new method for estimating soil water repellency index. Biologia, 70, 1450 1455.

Rajkai, K., Tóth, B., Barna, G., Hernádi, H., Kocsis, M., Makó, A., 2015. Particle-size and organic matter effects on structure and water retention of soils. Biologia, 70, 1456-1461.

Robinson, D.A., Jones, S.B., Lebron, I., Reinsch, S., Dominguez, M.T., Smith, A.R., Jones, D.L., Marshall, M.R., Emmett, B.A., 2016. Experimental evidence for drought induced alternative stable states of soil moisture. Scientific Reports, 6, 20018.

Rodný, M., Lichner, L., Schacht, K., Holko, L., 2015. Depthdependent heterogeneity of water flow in sandy soil under grass. Biologia, 70, 1462-1467.

Sándor, R., Lichner, L., Filep, T., Balog, K., Lehoczky, É., Fodor, N., 2015. Spatial variability of hydrophysical properties of fallow sandy soils. Biologia, 70, 1468-1473.
Šurda, P., Lichner, L., Nagy, V., Kollár, J., Iovino, M., Horel, Á., 2015. Effects of vegetation at different succession stages on soil properties and water flow in sandy soil. Biologia, 70, 1474-1479.

Ward, P.R., Roper, M.M., Jongepier, R., Micin, S.F., 2015. Impact of crop residue retention and tillage on water infiltration into a water-repellent soil. Biologia, 70, 1480-1484.

Yasutake, D., Mori, M., Kitano, M., Nomiyama, R., Miyoshi, Y., Hisaeda, D., Cho, H., Tagawa, K., Wu, Y., Wang, W.Z., 2015. Night-time leaf wetting process and its effect on the morning humidity gradient as a driving force of transpirational water loss in a semi-arid cornfield. Biologia, 70, $1485-1489$.

Zhao, Y., Peth, S., Hallett, P., Wang, X., Giese, M., Gao, Y., Horn, R., 2011. Factors controlling the spatial patterns of soil moisture in a grazed semi-arid steppe investigated by multivariate geostatistics. Ecohydrology, 4, 36-48. 